\title{
SERGANČIŲJŲ COVID-19 INFEKCIJA DEGUONIES TERAPIJOS BŪDAI IR EFEKTYVUMAS INTENSYVIOSIOS TERAPIJOS SKYRIUJE
}

\author{
Gintarė Iveta Semėnaitė ${ }^{1}$, Viktorija Mačiulytė ${ }^{1}$, \\ Jurgita Borodičiené2 ${ }^{2}$ Andrius Macas ${ }^{2}$ \\ ${ }^{1}$ Lietuvos sveikatos mokslu universitetas, Medicinos fakultetas \\ ${ }^{2}$ Lietuvos sveikatos mokslu universitetas, Medicinos fakultetas, Anesteziologijos klinika
}

Raktažodžiai: Covid - 19, deguonies terapija, intensyviosios terapijos skyrius.

\begin{abstract}
Santrauka
Pasaulinè Covid - 19 pandemija, sukèlusi daug sunkumų sveikatos apsaugos sistemai, paskatino gydytojų bendruomenès diskusijas apie deguonies terapiją, jos taikymo būdus ir galimybes bei ligos baigtis. Šio tyrimo tikslas - išanalizuoti ir pristatyti pacientų, sirgusių COVID-19 infekcija ir gydytu intensyviosios terapijos skyriuje, gydymo ypatybes bei ligos baigtis. Tyrimo metu pastebèta, kad vieno, perspektyvesnio ir geresnius gydymo rezultatus teikiančio deguonies terapijos būdo išskirti negalima. Pacientų, sergančių Covid-19 infekcija, gydymo priemonès ir rezultatai skiriasi, o tai rodo, kad ventiliacijos valdymo metodai turètų būti parenkami individualiai, atsižvelgiant ị kiekvieno paciento būklę ir poreikius.
\end{abstract}

\section{İvadas}

Naujasis koronavirusas 2 (SARS-CoV-2) nuo pasaulinès pandemijos pradžios $2020 \mathrm{~m}$. pirmajame ketvirtyje iki šiol kelia sunkumų visai sveikatos apsaugos sistemai. Oro lašeliniu būdu perduodamas virusas gali sukelti besimptomę, lengvą (nèra pneumonijos), vidutinę (yra pneumonija), sunkią (dispnèja, kvẻpavimo dažnis $30 \mathrm{k} / \mathrm{min}$, deguonies saturacija mažiau $93 \%, \mathrm{PaO}_{2} / \mathrm{FiO}_{2}$ santykis mažesnis nei 300 ir (ar) plaučių infiltracija siekia 50\% ir daugiau viso plaučiu ploto per 24-48 valandas) ir labai sunkią (sunkus kvėpavimo nepakankamumas, septinis šokas, dauginè organų disfunkcija ar nepakankamumas) Covid - 19 ligos formą [1]. Pastebèta, kad vyresni, daugiau gretutinių ligų ir būklių turintys pacientai yra labiau pažeidžiami, turi didesnę tikimybę sirgti sunkia ir labai sunkia ligos forma, būti hospitalizuoti. Pacientų su gretutinemis ligomis mirtingumas nuo Covid - 19 yra didesnis, nei bendrosios populiacijos [2-3].
Koronaviruso sukeltas sunkus ūminis respiracinis sindromas sukelia sunkius alveolių pažeidimus bei plaučių uždegimą pacientams, sergantiems Covid-19 liga. Hipokseminị kvėpavimo nepakankamumą sukelia plaučiu parenchimos konsolidacija ir dèl jos atsiradę kraujo dujų pokyčiai [4]. Toks kvepavimo nepakankamumas, remiantis naujausiomis rekomendacijomis, turètų būti kontroliuojamas deguonimi per nosies kaniules ar deguonies kaukę, deguonimi, tiekiamu per didelio srauto nosies kaniules, neinvazine teigiamo slégio ventiliacija ar dirbtine plaučių ventiliacija, pacientą intubavus [5-6]. Skirtinguose intensyviosios terapijos skyriuose stebimi skirtingi mirtingumo rodikliai, todèl keliama hipotezé, kad skirtingi pacientų deguonies terapijos ir ventiliacijos būdai turi ịtakos pacientų ligos baigtims [7]. Šis tyrimas buvo atliktas siekiant nustatyti deguonies terapijos metodus bei jų veiksmingumą pacientams, sergantiems COVID-19 ir gydomiems intensyviosios terapijos skyriuje.

Tyrimo tikslas - išanalizuoti ir pristatyti pacientų, sergančių COVID-19 infekcija ir gydomų intensyviosios terapijos skyriuje, gydymo ypatybes bei ligos baigtis.

\section{Tyrimo medžiaga ir metodai}

Tyrimas atliktas $2020 \mathrm{~m}$. lapkričio - $2021 \mathrm{~m}$. vasario mėnesiais Lietuvos sveikatos mokslų universiteto ligoninèje Kauno klinikose (LSMUL KK) Covid-19 sektoriuje. Buvo renkami Covid - 19 liga sergančių pacientų duomenys apie jų amžių, lyti, gretutines ligas ir deguonies terapijos būdus, užtikrinančius paciento adekvačią respiracinę funkciją. Visiems tiriamiesiems laboratorijoje PGR būdu buvo patvirtinta Covid-19 infekcija. Pacientams reanimacinis gydymas buvo reikalingas dèl Covid - 19 ligos arba dèl kitos būklès, kartu nustačius ir Covid - 19 infekciją.

Tyrimo duomenų analizè atlikta naudojant Microsoft Excel programinị paketą. 


\section{Tyrimo rezultatai}

Tyrime dalyvavo 103 pacientai (1 lentelè). Dauguma (94,1 proc.) turejjo gretutinių ligų, 56,8 proc. turejjo dvi ar daugiau gretutines patologijas. Dažniausiai pasireiškusi patologija (46,3 proc. pacientų) - širdies ir kraujagyslių sistemos ligos, tokios kaip arterinè hipertenzija, išeminè širdies liga, širdies nepakankamumas. Tarp pacientų, turejjusių vieną gretutinę ligą, 26 (64,3 proc.) pasireiškej kvèpavimo funkcijos nepakankamumas. Iš visų, turinčių dvi ar daugiau gretutiniu patologijų, 36 (66,7 proc.) pasireiškè kvèpavimo funkcijos nepakankamumas. 35,2 proc. dauginio ligotumo pacientu taikyta kombinuota deguonies terapija, 64,8 proc. tiriamuju kvèpavimo funkcija buvo užtikrinama tik vienu deguonies terapijos metodu.

78 (77,2 proc. ) pacientams intensyviosios terapijos skyriuje prireikè vienos ar daugiau kvėpavimą užtikrinančių priemonių. Deguonies terapija nuo minimalios $31 / \mathrm{min}$ deguonies tèkmès per nosies kaniules iki maksimalios 15 1/min tèkmès naudojant veido kaukę su rezervuaru buvo taikyta 46,2 proc. pacientų. 28,2 proc. ligonių taikyta neinvazinè plaučių ventiliacija, 26,9 proc. - naudotos didelès tẻkmès nosies kaniulés. 28,2 proc. pacientų buvo intubuoti ir naudota dirbtinè plaučių ventiliacija. Iš visų 78 pacientų, kuriems buvo taikoma bet kokia deguonies terapija, 38 dèl blogėjančios kvėpavimo funkcijos prireikè daugiau nei vieno deguonies terapijos metodo. Pacientų, kuriems pakako vieno deguonies terapijos metodo, dažnis pavaizduotas 2 lentelèje.

Pacientams deguonies terapija buvo taikoma ịvairiomis kombinacijomis. Kvėpavimą užtikrinančių priemonių naudojimo variacijos pateikiamos 3 lentelëje.

Mire 44 (43,56 proc.) intensyviosios terapijos skyriuje gydyti pacientai. 93,2 proc. mirusiujų turejjo gretutinių patologijų, 65,9 proc. - daugiau nei vieną gretutinę ligą. 38 (86,4 proc.) pasireiškẻ pneumonija, iš jų 37 (97,4 proc.)

1 lentelè. Tiriamujų charakteristikos.

\begin{tabular}{|l|c|}
\hline Tiriamujjų charakteristikos & Dažnis (proc.) \\
\hline Pacientų amžiaus vidurkis & $66,31 \mathrm{~m}$. \\
Jauniausias pacientas & $24 \mathrm{~m}$. \\
Vyriausias pacientas & $92 \mathrm{~m}$. \\
\hline Lytis: & \\
Vyrai & 52,5 \\
$\quad$ Moterys & 47,5 \\
\hline Gretutinės ligos: & 46,3 \\
\hline Širdies ir kraujagyslių sistemos ligos & 23,3 \\
\hline Šalinimo sistemos ligos & 21,1 \\
\hline Virškinamojo trakto ligos & 18,9 \\
\hline Onkologinès ligos & 16,8 \\
\hline Nervų sistemos ligos & 9,5 \\
\hline Kvèpavimo sistemos ligos & \\
\hline
\end{tabular}

ir kvėpavimo funkcijos nepakankamumas. Iš 44 mirusių asmenų, 19 (43,2 proc.) prireikè daugiau nei vienos kvèpavimą užtikrinančios priemonès. DPV prireikè 88,6 proc. pacientų, mažos tėkmès $\mathrm{O}_{2}$ terapija taikyta 22,7 proc., NIV $-31,8$ proc., $\mathrm{HF}-22,7$ proc. pacientu.

57 pacientai, pagerejus kvėpavimo funkcijai arba suformavus tracheostomą, esant stabiliems gyvybiniams rodikliams buvo perkelti i kitus terapinius skyrius arba pervežti pagal gyvenamają vietą $\mathfrak{i}$ artimesnę antro lygio ligoninę.

\section{Diskusija}

Mūsų tyrimo duomenimis, dauguma pacientų, gydytų LSMUL KK turèjo gretutinių ligų, 56,8 proc. tiriamujų turèjo dvi ar daugiau gretutinių ligų. Dažniausia gretutinè patologija - širdies ir kraujagyslių sistemos ligos. Panaši tendencija stebima ir kitose ligoninèse. F. Zhou ir kt. atliktame tyrime Kinijoje aprašoma, jog 48 proc. pacientų buvo dauginio ligotumo, vyraujanti patologija taip pat buvo kardiovaskulinès sistemos ligos [8]. Panaši studija atlikta T. Chen ir kt., kur dvi ar daugiau gretutinių ligų turintys pacientai sudare 49 proc., o vyraujanti patologija buvo arterinè hipertenzija [9].

T. Montrief ir kt. publikacijoje teigiama, kad deguonies terapija reikalinga daugiau nei 41 proc. Covid-19 infekcija sergančių pacientų [10]. Mūsų tyrimo duomenimis, net 77,2 proc. pacientų, gydytų intensyviosios terapijos skyriuje, reikèjo vienos ar daugiau kvėpavimą užtikrinančių priemonių. Mažos tėkmès deguonies terapija (deguonis skiriamas per nosies kaniules ar kaukę) - dažniausiai naudojama pradiné deguonies terapijos priemonè Covid-19 infekcija sergantiems

2 lentelè. Deguonies terapijos metodai, naudojant vieną deguonies terapijos priemonę.

\begin{tabular}{|l|c|}
\hline Deguonies terapijos metodas & Dažnis, n (proc.) \\
\hline O2 per nosies kaniules ar kaukę & $11(27,5)$ \\
\hline NIV & $1(2,5)$ \\
\hline High-flow & $1(2,5)$ \\
\hline DPV & $27(67,5)$ \\
\hline
\end{tabular}

3 lentelė. Deguonies terapijos metodai, naudojant kombinuotas deguonies terapijos priemones.

\begin{tabular}{|l|c|}
\hline Deguonies terapijos metodai & Dažnis, n (proc.) \\
\hline $\mathrm{O} 2 \rightarrow \mathrm{DPV}$ & $6(15,8)$ \\
\hline $\mathrm{O} 2 \rightarrow \mathrm{HF} \rightarrow \mathrm{NIV} \rightarrow \mathrm{DPV}$ & $2(5,7)$ \\
\hline $\mathrm{O} 2 \rightarrow \mathrm{HF}$ & $1(2,6)$ \\
\hline $\mathrm{O} 2 \rightarrow \mathrm{NIV} \rightarrow \mathrm{DPV}$ & $2(5,7)$ \\
\hline $\mathrm{HF} \rightarrow \mathrm{NIV} \rightarrow \mathrm{DPV}$ & $9(23,7)$ \\
\hline $\mathrm{HF} \rightarrow \mathrm{DPV}$ & $2(5,7)$ \\
\hline $\mathrm{HF} \rightarrow \mathrm{NIV}$ & $1(2,6)$ \\
\hline $\mathrm{NIV} \rightarrow \mathrm{DPV}$ & $2(5,7)$ \\
\hline $\mathrm{DPV} \rightarrow \mathrm{O} 2$ & $5(13,2)$ \\
\hline
\end{tabular}


pacientams, kuriems pasireiškè lengva hipoksija. Manoma, jog naudojant nosies kaniules yra minimalus aerozolių susidarymas, taigi, maža rizika platinti Covid-19 virusą. Ši priemonè buvo taikyra 46,2 proc. mūsų tiriamujųu. Didelès tèkmès nosies kaniulès (DTNK) tampa vis dažniau naudojama priemone suaugusiems asmenims, kuriems pasireiškia I tipo hipoksinis kvëpavimo funkcijos nepakankamumas be hiperkapnijos $[6,11]$. Retrospektyviniame kohortiniame tyrime, atliktame Kinijoje, DTNK terapija buvo taikoma 21 proc. pacientu, kuriems diagnozuota Covid-19 infekcija [12]. JAV mokslininkų atliktoje studijoje, 42 proc. sunkia Covid-19 infekcijos forma sergančių pacientų buvo taikytas šis metodas [13]. Mūsų atliktame tyrime DTNK oksigenoterapija buvo taikyta 26,9 proc. pacientų. Taip pat aprašoma, jog 14 proc. pacientų prieš intubaciją buvo gydomi DTNK deguonies terapija [14]. Mūsų tyrime - 5,9 procentai. Palyginti su neinvazine ventiliacija (NIV), šis metodas yra patogesnis bei lengviau toleruojamas. Viename atsitiktinių imčių tyrime aprašoma, kad taikant DTNK deguonies terapiją, 90 dienų mirtingumas buvo mažesnis, nei naudojant NIV ar DPV [15]. Neinvazinès ventiliacijos (NIV) priemonès, kaip ir DTNK, gali padèti atitolinti ir išvengti paciento intubacijos ir DPV taikymo. Naujausiais duomenimis, net iki 70 proc. Covid-19 infekcija sergančių pacientų buvo taikoma NIV prieš intubaciją ir dirbtinę plaučių ventiliaciją [16-17]. Neinvazinė plaučių ventiliacija taikyta 28,2 proc. mūsų tiriamujų. Nèra aiškių rekomendacijų, kuomet reikètų intubuoti COVID-19 infekcija sergančius pacientus. Šie pacientai gerai toleruoja hipoksemiją, todèl didelis dèmesys turètų būti skiriamas klinikiniam paciento vertinimui. Kai kurie tyrimai nurodo, jog 10-17 proc. Covid-19 infekcija sergančiuc pacientų galiausiai prireikia intubacijos bei dirbtinès plaučių ventiliacijos [18-20]. Mūsų atliktame tyrime DPV taikyta 28,2 proc. pacientų. Trečdaliui pacientų dẻl blogèjančios kvẻpavimo funkcijos prireikẻ daugiau nei vienos kvẻpavimą užtikrinančios priemonès.

Mūsų atlikto tyrimo duomenimis, mire 43,56 proc. intensyviosios terapijos skyriuje gydytų Covid-19 infekcija sergančių pacientų. C. Huang ir kt. atliktoje studijoje mirusių pacientų skaičius sudare 38 procentus [20]. Kiek didesnis mirtingumas aprašytas X. Yang ir kt. publikacijoje, kai mirusių pacientų skaičius siekè 61,4 procento. 86 proc. pacientų, kurie mirè, buvo taikoma DPV [21]. 88,6 proc. mūsų tiriamujų, kurie mirè, buvo taikoma DPV.

\section{Išvados}

1. Taikant įvairius kvėpavimo funkciją užtikrinančius metodų derinius, Intensyviosios terapijos skyriuje kombinuota deguonies terapija buvo gydyta 48,7 proc. visų pacientų, iš kurių 43,2 proc. pacientų mirè.
2. Dažniausias pradinis deguonies terapijos metodas visiems pacientams buvo mažos tėkmès deguonies terapija (deguonies tiekimas per nosies kaniules ar kaukę su rezervuaru). Daugumai pacientų dèl sunkios būklès prireikè intubacijos ir dirbtinès plaučių ventiliacijos, tačiau šie pacientai mirè.

3. Pacientų, sergančių Covid-19 infekcija, gydymo priemonès ir rezultatai skiriasi, o tai rodo, kad ventiliacijos valdymo metodai turètų būti parenkami individualiai, atsižvelgiant ị kiekvieno paciento būklę ir poreikius.

\section{Literatūra}

1. Umakanthan S, Sahu P, Ranade AV, Bukelo MM, Rao JS, Abrahao-Machado LF, et al. Origin, transmission, diagnosis and management of coronavirus disease 2019 (Covid-19). Postgrad Med J 2020;96(1142):753-8.

2. Lithander FE, Neumann S, Tenison E, Lloyd K, Welsh TJ, Rodrigues JCL, et al. SC interventions at the university of Bristol in partnership with public health England. JPTH is supported Institute for Health Research Health Protection Research Unit (NIHR HPRU) in evaluation of interventions at the university of Bristol in partners. 2020;1-5.

3. Grasselli G, Greco M, Zanella A, Albano G, Antonelli M, Bellani $\mathrm{G}$, et al. Risk factors associated with mortality among patients with Covid-19 in intensive care units in Lombardy, Italy. JAMA Intern Med 2020;180(10):1345-55.

https://doi.org/10.1001/jamainternmed.2020.3539

4. Baig AM. Computing the effects of SARS-CoV-2 on respiration regulatory mechanisms in Covid-19. ACS Chem Neurosci 2020;11(16):2416-21.

https://doi.org/10.1021/acschemneuro.0c00349

5. Cook TM, El-Boghdadly K, McGuire B, McNarry AF, Patel A, Higgs A. Consensus guidelines for managing the airway in patients with Covid-19: guidelines from the Difficult Airway Society, the Association of Anaesthetists the Intensive Care Society, the Faculty of Intensive Care Medicine and the Royal College of Anaesthetists. Anaesthesia 2020;75(6):785-99. https://doi.org/10.1111/anae.15054

6. Jovaiša T, Macas A, Pilvinis V, Pranskūnas A, Šipylaite J, Vosylius S, et al. Covid-19 praktinès gydymo ir slaugos rekomendacijos intensyviosios terapijos skyriuje, 2020.

7. Marini JJ, Hotchkiss JR, Broccard AF. Bench-to-bedside review: microvascular and airspace linkage in ventilator-induced lung injury. Crit Care 2003;7(6):435-44.

https://doi.org/10.1186/cc2392

8. Zhou F, Yu T, Du R, Fan G, Liu Y, Liu Z, et al. Clinical course and risk factors for mortality of adult inpatients with Covid-19 in Wuhan, China: a retrospective cohort study. Lancet 2020;395(10229):1054-62. https://doi.org/10.1016/S0140-6736(20)30566-3

9. Chen T, Wu D, Chen H, Yan W, Yang D, Chen G, et al. Clinical characteristics of 113 deceased patients with coronavirus dis- 
ease 2019: retrospective study. BMJ.

10. MontriefT, Ramzy M, Long B, Gottlieb M, Hercz D. Covid-19 respiratory support in the emergency department setting. Am J Emerg Med. 2020;38(10):2160-8. https://doi.org/10.1016/j.ajem.2020.08.001

11. Koga Y, Kaneda K, Fujii N, Tanaka R, Miyauchi T, Fujita M, et al. Comparison of high-flow nasal cannula oxygen therapy and non-invasive ventilation as first-line therapy in respiratory failure: a multicenter retrospective study. Acute Med Surg 2020;7(1):1-7.

https://doi.org/10.1002/ams2.461

12. Wang D, Hu B, Hu C, Zhu F, Liu X, Zhang J, et al. Clinical Characteristics of 138 Hospitalized Patients with 2019 Novel Coronavirus-Infected Pneumonia in Wuhan, China. JAMA - J Am Med Assoc 2020; 323(11):1061-9. https://doi.org/10.1001/jama.2020.1585

13. Bhatraju PK, Ghassemieh BJ, Nichols M, Kim R, Jerome KR, Nalla AK, et al. Covid-19 in critically Ill patients in the Seattle region - case series. N Engl J Med 2020;382(21):2012-22. https://doi.org/10.1056/NEJMoa2004500

14. Xie J, Tong Z, Guan X, Du B, Qiu H. Clinical characteristics of patients who died of coronavirus disease 2019 in China. JAMA Netw Open 2020;3(4):e205619.

https://doi.org/10.1001/jamanetworkopen.2020.5619

15. Lucchini A, Giani M, Isgrò S, Rona R, Foti G. The "helmet bundle" in COVID-19 patients undergoing non invasive ventilation. Intensive Crit Care Nurs 2020;58(xxxx):1-2. https://doi.org/10.1016/j.iccn.2020.102859

16. Namendys-Silva SA. Respiratory support for patients with COVID-19 infection. Lancet Respir Med 2020;8(4):e18. https://doi.org/10.1016/S2213-2600(20)30110-7

17. Alhazzani W, Møller MH, Arabi YM, Loeb M, Gong MN, Fan E, et al. Surviving sepsis campaign: guidelines on the management of critically ill adults with coronavirus disease 2019 (Covid-19). Intensive Care Medicine 2020;46:854-887. https://doi.org/10.1007/s00134-020-06022-5

18. Huang C, Wang Y, Li X, Ren L, Zhao J, Hu Y, et al. Clinical features of patients infected with 2019 novel coronavirus in Wuhan, China. Lancet 2020;395(10223):497-506.

https://doi.org/10.1016/S0140-6736(20)30183-5
19. Jiang B, Wei H. Oxygen therapy strategies and techniques to treat hypoxia in Covid-19 patients. Eur Rev Med Pharmacol Sci 2020;24(19):10239-46.

20. Yao W, Wang T, Jiang B, Gao F, Wang L, Zheng H, et al. Emergency tracheal intubation in 202 patients with COVID-19 in Wuhan, China: lessons learnt and international expert recommendations. Br J Anaesth 2020;125(1):e28-37.

21. Yang X, Yu Y, Xu J, Shu H, Xia J, Liu H, et al. Clinical course and outcomes of critically ill patients with SARS-CoV-2 pneumonia in Wuhan, China: a single-centered, retrospective, observational study. Lancet Respir Med 2020;8(5):475-81. https://doi.org/10.1016/S2213-2600(20)30079-5

\section{METHODS AND EFFECTIVENESS OF OXYGEN THERAPY FOR PATIENTS WITH COVID-19 \\ G.I. Semènaitė, V. Mačiulytė, J. Borodičienė, A. Macas}

Keywords: Covid - 19, oxygen therapy, intensive care unit.

Summary: The global Covid - 19 pandemic has not only caused many challenges to the healthcare system but has also led the medical community to discuss oxygen therapy, its applications and options, and patient outcomes associated with it. In this study, we look at patients with Covid - 19 treated in the intensive care unit at the Clinic of Anesthesiology, Kaunas Clinics, Lithuanian University of Health Sciences. Study analyzes their treatment with oxygen therapy as well as outcomes: oxygen supply methods, device combinations, and patients' ${ }^{6} \mathrm{co}-$ morbidities. The study found that one, more promising and superior treatment regimen for oxygen therapy could not be identified. Patients with Covid-19 infection have different treatments and outcomes, suggesting that ventilation management methods should be selected on an individual basis, taking into account the condition and needs of each patient.

Correspondence to: viktorija.maciulyte1@gmail.com

Gauta 2021-05-04 